JOURNAL OF AWARENESS

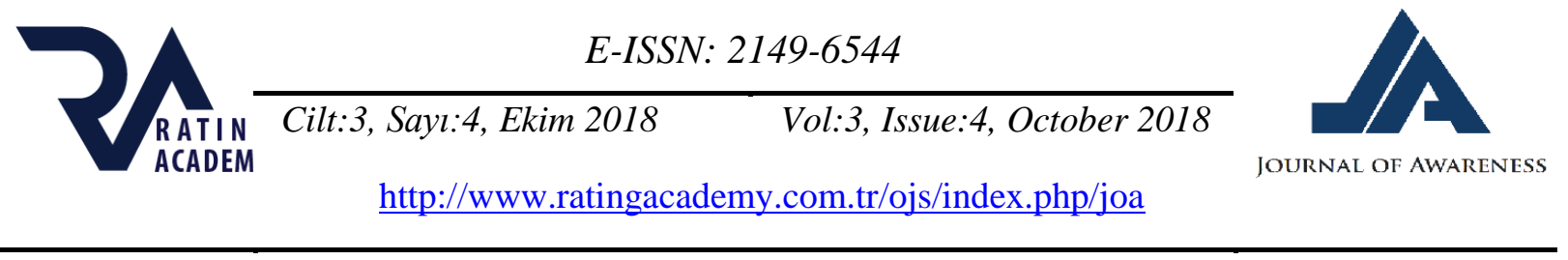

\title{
CYCLE TOURISM AS AN ALTERNATIVE WAY OF TOURISM DEVELOPMENT IN ÇANAKKALE, TURKEY
}

\author{
Assoc. Prof. Dr. Erol DURAN \\ Çanakkale Onsekiz Mart University, Faculty of Tourism, \\ Department of Accommodation Management, Çanakale,/TURKEY \\ E-mail: eroldurantr@yahoo.com \\ Instuctor Figen SEVINÇ \\ Bartin University, Vocational School, \\ Travel-Tourism and Entertainment Services, Bartın/TURKEY \\ E-mail:fsevinc@bartin.edu.tr \\ Assoc. Prof. Dr. Serhat HARMAN \\ Mardin Artuklu University, Faculty of Tourism, Mardin/TURKEY \\ E-mail: harmanserhat@gmail.com
}

\begin{tabular}{|c|c|}
\hline ARTICLE INFO & ABSTRACT \\
\hline $\begin{array}{l}\text { Article History: } \\
\text { Received: } 19 \text { July } 2018 \\
\text { Accepted: } 4 \text { October } 2018\end{array}$ & \multirow{3}{*}{$\begin{array}{l}\text { The number of the cyclists participating tourism activities in the world is gradually } \\
\text { increasing. The cycle tourism, having emerged from people's travelling by bike } \\
\text { according to their own motives, is becoming more popular, cycle routes are } \\
\text { getting enlarged, and projects are developed for cycle tours day by day. } \\
\text { Therefore, the elements constituting the cycle tourism have come into prominence } \\
\text { and the motivations of the cycle tourists participating bike tours have been studied. } \\
\text { Thus, the aim of this study is to find out the importance that cycle tourists give and } \\
\text { the level of the interest they show for cycle tours. The central question of the study } \\
\text { raised on is; "what is the level of interest and on cycling and how it can be an } \\
\text { important touristic attraction for Çanakkale tourism?" For this purpose, in-depth } \\
\text { interview technique was used on cyclist groups at different cycle tours in } \\
\text { Çanakkale, Turkey. According to the results of the analyses, developing cycling } \\
\text { by its philosophy and structural requirements in Çanakkale can be feasible in } \\
\text { sustainability perspective. }\end{array}$} \\
\hline $\begin{array}{l}\text { Keywords: Cycle tourism, } \\
\text { cycle tourist, cyclist, cycle } \\
\text { tour }\end{array}$ & \\
\hline $\begin{array}{l}\text { DOI: } \\
\text { 10.26809/joa.2018445552 }\end{array}$ & \\
\hline
\end{tabular}

\section{INTRODUCTION}

Technological developments, the decrease in the work hours and holidays' becoming a social right have directed people to their personal skills, self- actualization and the activities they take pleasure at their leisure time (Hazar, 2014). There are several internal and external motivations on participation to these activities (Porter and Lawyer, 1968; Sung, 2000). Because people's interest in an activity, the importance they give it and the profit they gain from participating (status, success, pleasure etc.) play an important role for turning towards these activities (Sung, 2000). 
People, prefer activities, which relax them in terms of physical, mental and spiritual aspects that are enjoyable, satisfactory, pleasurable, and can always be done in their leisure time. One of these is cycling, which has had a place in people's lives and has been preferred for transportation and sportive aims for a long time. The similar and safe use of bicycle structure, which dates back 1890s (Wilson, 2004), is examined in an extensive scope from physical and rural recreation to sportive and touristic recreation with regard to participation to touristic activities (Hazar, 2014; Garda, 2014) and to special interest tourism to outdoor adventure tourism (Morpeth, 2001; Weber, 2001; Pomfret, 2006). Cycle tours have been organized through both travel agents and digital networks. Therefore, the opportunity is provided for everybody to come together, who wish to be in nature, travel a lot of places in a short time, work out, challenge, experience such feeling as excitement, happiness and risk together; and are interested in adventure with bike.

It has been observed that cycle tourism has turned into a center of interest, cycle routes have been enlarged and the projects for cycling tour have been developed day by day. In spite of the realized studies about cycle tourism, studies on motivation of tourists related to cycling tour are limited. Considering the theoretical gap in the literature, the purpose of this study is to determine the importance that cycle tourists give cycle tours and level of their interest. In addition, this study aims to contribute to the tourism potential of the cycling by its conceptual structure and to investigate the popularity on cycling tourists and local cyclists on development of Çanakkale tourism.

\section{LITERATURE REVIEW}

Cycle tourism, which has frequently been mentioned in connection with adventure tourism, sports tourism, special interest tourism, nature tourism, rural tourism and sustainable tourism recently, takes place in literature as a type of tourism, of which importance has been appreciated more day by day (Ritchie, 1998; Piket, Eijgelaar \& Peeters 2013; Lee and Huang, 2014; Nickerson, Jorgenson, Berry, Kwenye, Kozel \& Schutz 2014; Payne and Dror, 2015; Aşan and Akoğlan Kozak, 2015; Kaplan, Manca, Nielsen \& Prato 2015; Okonski, 2016; Han, Meng \& Kim, 2017). Upon reviewing the definitions on cycle tourism (Sustrans, 1999; Lumsdon, 2000; Bloy, 2001; South Australian Tourism Commission, 2005; Lamont, 2009; Beanland, 2013; Piket et al., 2013) it is seen that a variety of definitions have been made regarding what kind of a tourism type it is by considering the outstanding elements in cycle tourism and the features of cycle tourism. In some of the definitions, while bicycle-based trips and touristic activities are distinguished for special interests such as pleasure, sport, racing, recreational activities, and hobbies; the fields where the activities are organized and the importance of their components are emphasized in some definitions. In generally, cycle tourism attributes to travel between destinations by bicycle for leisure purposes and cycling is an integral part of the tourist experience (European Parliament, 2012). In a broader sense, cycle tourism includes the trips taken along a specific route to explore destinations by bicycle with the purpose of doing sports, adventure seeking, challenge, physical, mental and spiritual relaxation, entertainment, being closer to nature etc. The growth of the use of the bicycle which is a sustainable form of sports, recreation and tourism activities, together with the development of cycle tourism, forms a good basis to develop a sustainable, intelligent, inclusive society (Gantar, Kocis \& Pehnec, 2012). Thus, cycle tourism which plays a role to boost rural economies also has a sustainable feature in terms of social and environmental aspect (Carre, 1992; Cushing, 1997; Simonsen, Jorgensen \& Robbins 1998; Ritchie and Hall, 1999; Bloy, 2001; Faulks, Ritchie \& Fluker 2006; Koch, 2013; Beanland, 2013).

It has become important to determine the market share and the tourist profile of the cycle tourism that has important economic potential is coming into prominence day by day (Ritchie, 
1998). Hence, Larson (1995) claimed that 27.5 million adults are cycling for social or recreational purposes in America and this number is increasing even more. Keeling (1999), on the other hand, predicted that cycle tourism, which has already a sizeable market, will display a considerable growth in the following decade. Especially, in the UK, a large part of the predicted increase in trade is considered to be linked to the development of the Sustrans-inspired National Cycle Network (NCN). Sustrans (1999) claimed that cycle tourism provides almost $\% 50$ percent of the estimated UK leisure cycling market ( $£ 285$ million of the $£ 635$ million). Besides, cycle holidays contribute $£ 142$ million to the amount in question every year. Moreover, the European Parliament (2012) noted that more than 2.2 billion cycle tourism trips and 20 million over-night cycle trips are organized annually in Europe and their share in the economy is expected to be $€ 44$ billion. To be in the cycle route and to decide the cycle routes in Europe have become important also with the impact of economic, social and sustainable benefits. Therefore, such institutions as Sustrans, European Cyclists Federation, the European cycle route network, Cycling Embassy decide routes, and arrange organizations and tours for the development of this type of tourism (Davis, n.d; EuroVelo, n.d; Lancaster, n.d; Sustrans, 2015). The cycle tours getting more popular in European countries and the economic contribution of the cycle tourists have ensured that cycle tourism has an undeniable place in the tourism income (Carre, 1992; Cushing, 1997; Bloy, 2001). Therefore, the countries desiring to make investment in this tourism, to create enlarged cycle routes and to be in the cycle route in the international dimension, make attempts for cycle tourism and develop various projects. Even it is observed that some defunct rail lines are rearranged and turned into bicycle roads (Ritchie, 1998; Simonsen et. al. 1998).

The increasing interest for cycle tourism has not just brought about a strong competition between European countries (Koch, 2013), but also expanded worldwide. Because possessing geographical advantages, natural beauties, historical and cultural wealth etc. gives rise to the development of cycle tourism in destinations and makes progress in Asia following America and Europe (Lu, 2010). Turkey, thanks to her location, natural and historical beauties, safe and alternative cycle routes, attracts the attention of tour organizers and cycle tourists. For instance, there are currently 15 EuroVelo long distance cycle routes connecting and uniting the whole European continent, forming the European cycle route network and Turkey has been included to EuroVelo 13 recently also estimated that the network will be complete by 2020 . All of these approximately $70.000 \mathrm{~km}$ routes can be used by cyclists daily (EuroVelo, n.d). Thus, determining the reasons playing role in cycle tourists' turning towards destinations, cycle tours contributes both to the development of tourism and creating balance between supply and demand for its sustenance. It is possible to claim that the increase of the demand for this tourism type and its development recently have positive affect on importance of the studies related to cycle tourism in Turkey in recent years. Because, the number of the cyclists gradually increasing in Turkey. According to the researchers social/recreational and transportation aims are among the reasons for people's biking increased and (Ardahan and Mert, 2014; Günaydın, 2015), a similar sample of results noted that both physical and psychological benefits are also gained (Koçak, 2016).

According to the common findings obtained in studies, the main motivations of the cycle tourists can be listed as keeping their health, looking for adventure, doing recreational activity, being in new destinations in nature and being away from the crowd etc (Simonsen et. al. 1998; Bloy, 2001; European Parliament, 2012; Gantar et. al. 2012). Additionally, the presence of local, national and international bicycle networks, the activities of their communities, bicycle races, fests, activities and their reaching to masses thanks to social media have contributed to the increase in the number of cycle tourists and their turning towards international trips. 


\section{METHODOLOGY}

This study, examines importance of cycling for tourists and the level of the interest they show for cycle tours. Çanakkale also has opportunities that can be an important touristic attraction such as possessing geographical advantages, natural beauties, historical and cultural wealth for being cycle routes. Moreover it is observed that cycle tourists periodically travel as a couple or in small groups. Therefore, this study was focused on these tourist groups who travel by bike in a group in Çanakkale region. Thus, qualitative data via interview technique was used in this study to gain in-depth knowledge about popularity of cycling in Çanakkale and cultural structure of this touristic attraction. The problem of the study is also "what is the level of interest and importance on cycling and how can be an important touristic attraction for Çanakkale tourism?

Since social sciences are proved to be a confident field for qualitative research methods, interview technique was preferred to determine the meaning of cycling concept in a cyclists' life and the potential of cycle tourism as an alternative in terms of Çanakkale tourism. Furthermore, content analysis was used for solving and interpreting the findings. Content analysis is a research method which allows the qualitative data collected in research to be analyzed systematically and reliably so that generalizations can be made from them in relation to the categories of interest to the researcher (Haggarty, 1996, Hamarat, 2017).

The data were collected primarily through recorded interviews in the study and open ended questions were used. The data analysis starts with reading all data reiteratively to achieve impression and obtain a sense of the whole (Hsieh and Shannon, 2005) like a novel. Then, recorded data were listened and written on Microsoft office word program and read word by word to derive codes (Huberman and Miles, 2002) by first highlighting the exact words from the text that appear to capture key thoughts or concepts. Next the text was examined by making notes of first impressions, thoughts and initial analysis. As this process continues, labels for codes were emerged that are reflective of more than one key thought. Then codes were sorted into categories based on how different codes were related and linked. These emergent categories were used to organize and group codes into meaningful clusters (Patton, 2002). Those systematic were also followed for analyzing the technique which was used in this study.

The interviews were semi-structured and the population was consisted of 35 cyclists. The interviewees were selected during the cycling tours by snowball sampling. The questions directed to the interviewees were as follows;

- What is the importance of cycling in your life and mind?

- What is the significance of cycling in your recreational and social attractions?

- In your opinion what is the significance of cycling on recreational and cultural structure of Çanakkale?

- What is the frequency of cycling in your monthly life?

- Do you think that developing and sustaining cycling by its philosophy and structural ingredients would gain touristic and cultural structure of Çanakkale?

- How do you feel during the cycling?

- Do you think that cycling should be a touristic product for Çanakkale?

Content analysis was used in this study and steps of the analysis conducted are summarized as follows. The data gathered was coded by the researcher and there are various ways of coding (Günlü et al., 2009);

- Coding according to previously identified concepts,

- Coding according to the concepts identified through the data being analyzed,

- Coding in a general framework. 
The second coding type "coding according to the concepts identified through the data being analyzed" is preferred in this study since there is no previously defined conceptual structure guiding the analysis of the data.

- Axial coding; coding on classifying the data should be supported with another step as connecting the codes under an axial framework.

- Selective coding; phenomenon of the research is identified and the core category is emphasized.

- Setting and describing codes according to main themes.

- Connecting on the findings, conclusion and discussion.

As long as the data are analyzed, one of the most important things in qualitative research is to test the validity and reliability of the research. In order to test the validity of the research, two independent scholars were selected from Çanakkale Onsekiz Mart University and were asked to investigate the original answers from interviewees, and rate the codes. As soon as they coded and calculated the rates separately, codes from independent scholars and from authors were compared, responses were collected and the right percentage was calculated by the authors. After coding, code lists were classified in themes according to the common directions.

\section{FINDINGS}

The demographic composition of the cyclist profile reflects the nature of the town itself, being a college town with Çanakkale Onsekiz Mart University and housing a significant number of educators, professionals and retirees alike. However gender distribution of cyclists was not well balanced, with 10 per cent female and 90 per cent male. Almost all of the cyclists have a college and higher education degree (90.1 per cent). Just 40 per cent of cyclists are students, and the remaining 60 per cent represents the categories of professionals ( 20 per cent), educators (12 per cent) and others (28 per cent). Slightly 40 per cent of cyclists reported monthly income of $+3,000 \mathrm{TL}(+\$ 1,000)$ and 45 per cent reported $+5,000 \mathrm{TL}(+\$ 1500) .40$ per cent of the cyclists are between 15-29 ages, 30 per cent of them are between 30-49 and 30 per cent are older than 50. Of the cyclists, 60 per cent declared that they were attending cycle tours more than 2 years and just 70 per cent of the cyclists declared that they attend the cycle tours almost every week. Almost all of the cyclists were attending tours with their friends. The frequencies of the codes in themes are emphasized on Table 1. 
Table 1. Frequencies of the codes and themes between interviewees

\begin{tabular}{|l|l|c|}
\hline \multicolumn{1}{|c|}{ Themes } & \multicolumn{1}{|c|}{ Codes listed according to themes } & Total mentions \\
\hline \multirow{4}{*}{ Importance of cycling } & Very much & 21 \\
\cline { 2 - 3 } & Average & 10 \\
\cline { 2 - 3 } & Not important & 4 \\
\hline \multirow{4}{*}{ Meaning of cycling } & Meaning of my life & 6 \\
\cline { 2 - 3 } Şanakkale & The most satisfied attraction & 12 \\
\cline { 2 - 3 } & Central of my social life & 6 \\
\cline { 2 - 3 } & Only an instrument of socialization & 11 \\
\hline \multirow{4}{*}{ Tourism potential } & A disregarded attraction & 15 \\
\cline { 2 - 3 } & Unimproved infrastructure & 18 \\
\cline { 2 - 3 } & Not massive & 12 \\
\hline \multirow{3}{*}{ Membership } & Natural routes & 13 \\
\cline { 2 - 3 } & Historical routes & 15 \\
\cline { 2 - 3 } & Extreme routes & 9 \\
\cline { 2 - 3 } & Routes with optional attractions & 17 \\
\cline { 2 - 3 } & Yes & 25 \\
\cline { 2 - 3 } & No & 6 \\
\cline { 2 - 3 } & Hesitant & 4 \\
\hline
\end{tabular}

As can be seen in Table 1, interviewees declared that cycling is an important attractive element of their life which means the most satisfied attraction and an important instrument of socialization between other people. Interviewee 11 emphasized that;

"I join cycling tours almost every week. I love cycling because, I can interact the people who have the same treats, life philosophies, enjoyments, etc. This situation makes me so discharged from daily life stress and so happy because of sharing valuable time."

(From interviewee I.13)

Interviewees indicated that cycling is a disregarded attraction in Çanakkale because of inadequate infrastructure that affects cycling negatively and cause to be only an individual attraction of weekends.

"In my opinion, cycling is very important for developing tourism in a sustainable way with high diversity of alternatives. But infrastructure of the city is not adequate to develop cycling not only a kind of tourism attraction but also a life philosophy for city life and residents. It must be a massive transportation vehicle.

(From interviewee I. 18).

This suggests that Çanakkale has a huge range of attractiveness on cycle tourism with characteristics of its' cycling routes (natural, historical, extreme etc.). According to interviews and the analysis about the interviews, It is almost certain that developing cycling as a touristic phenomenon and as a philosophical item for city life in sustainability perspective can gain positive effects for the city and residents.

\section{CONCLUSION}

People's preferring bicycle as means of transport in their daily life in developed societies and participating in the touristic activities more and more is an important step for environmental sustenance in addition to physical benefit. Because the new tourist profile of today, while giving importance to spiritual and physical health, and wishing to realize their wants to do sports and be close to nature, also pays attention to be beneficial to their environment and not to harm it. 
In addition, the cycle tourists who participate the tours prefer experiencing cultural exchange one by one than adapt to the lifestyle of that region as an exciting holiday. This study examines importance of cycling for tourists and the level of the interest they show for cycle tours in Çanakkale. Thus, represents an attempt to opinions these tourist groups who travel by cycles with cycling groups in Çanakkale region.

The present study's findings contributes to the current literature by demonstrating that the city of Çanakkale has a big variety of cycling tour routes with a big variety of cultural, natural, historical and structural instruments and with a high variety of difficulty levels. This study indicates that cycling should be developed with its structural and philosophical requirements in sustainability perspective to Çanakkale tourism as a cycle tourism destination. There are several limitations in this study. Firstly the sample population of this study may not include cyclists in Çanakkale. The current study is limited by being focused on only one destination during the cycling tours. This was due to time and funding constraints and the difficulty of monitoring or observing the performance of cyclists in Çanakkale. It would be desirable to replicate this study in different settings. For instance, future research might investigate toward extensive group whether importance of cycling for tourists and the level of the interest they show for cycle tours in different destinations. 


\section{REFERENCES}

ARDAHAN, F. and Mert, M. (2014). Bisiklet Kullanan Bireylerin Profillerinin Belirlenmesi ve Bireyleri Bisiklet Kullanmaya Motive Eden Faktörlerin Çeşitli Demografik Değişkenlere Göre Değerlendirilmesi: Türkiye Örneği. Türkiye Klinikleri Journal of Sports Sciences, 6(2): 53-67.

AŞAN K. and Akoğlan Kozak M. (2015). Postmodern turist deneyimi ve bisiklet turizmi, International Journal of Eurasia Social Sciences, 6 (21): 265-288.

BEALAND, A. (2013). Cycle tourism for sustainable rural development: Understanding and interpreting lessons from Europe, A Report of a Winston Churchill Traveling Fellowship 2013, The Winston Churchill Memorial Trust: London

BLOY, D. (2001). Understanding cycle tourist. Sheffield Hallam University.

CARRE, J. R. (1992). La situation de la bicyclette en France. In The Bicycle: Global Perspectives, Boivin, R. and Provonost, J. (eds.) Pro Bike Conference Proceedings Velo City.

CUSHING, S. (1997). The tourism potential of the national cycle network routes. Tourism Society Seminar, London, 20 October 1997.

DAVIS, J. (n.d). Cycling Embassy of Great Britain. Retrieved January 9, 2017, from http://www.cycling-embassy.org.uk

EUROPEAN Parliament (2012), Directorate general for internal policies policy department B: Structural and cohesion policies transport and tourism the European cycle route network Eurovelo. Retrieved December 20, 2016, from http://www.europarl.europa.eu/

EURO VELO, (n.d.) The European Cycle Route Network, Organisation Retrieved January 8, 2017, from http://www.eurovelo.org

FAULKS, P., Ritchie, B.W. and Fluker, M. (2006). Cycle tourism in Australia: An investigation into its size and scope Cooperative Research Centre for Sustainable Tourism.

GANTAR, A., Kocis, D. and Pehnec, M. (2012). How to develop cycle tourism? Rotar, J. (ed.) Retrieved from http://bicy.it/docs/35/How_to_develop_cycle_tourism_ang.pdf

GARDA, B. (2014). Macera Turizmi Pazarlaması Özel İlgi Turizminin Yeni Yüzü, Çizgi Kitapevi: Konya.

GÜNAYDIN, L. (2015). Demiryolu Bisikleti: Günümüzde Kullanilmayan Kirklareli-Büyük Mandira Demiryolu Hatti İçin Öneriler, EJOVOC Electronic Journal of Vocational Colleges. 5 (4): 86-93.

GÜNLÜ, E., Pırnar, I, Yağcı, K., (2009), Preserving Cultural Heritage and Possible Impacts on Regional Development: Case of İzmir, International Journal of Emerging and Transition Economies, 2 (2): 213-229.

HAGGARTY, L. (1996), What is ... Content Analysis? Medical Teacher, 18 (2): 99-101.

HAN, H., Meng, B. and Kim, W. (2017). Emerging bicycle tourism and the theory of planned behavior, Journal of Sustainable Tourism, 25 (2): 292-309.

HAMARAT, B. (2017). SPSS ve MINITAB Uygulamalı Istatistik. Paradigma Akademi Yayınları, Çanakkale.

HAZAR, A. (2014). Rekreasyon ve Animasyon, Detay Yayıncılık: Ankara. 
HSIEH, H. F., Shannon, E. S. (2005), Three Approaches to Qualitative Content Analysis, Qualitative Health Research, 15 (9): 1277-1288.

HUBERMAN, A., Miles, B. M. (2002). The Qualitative Researcher's Companion, Sage Publications Inc. Thousand Oaks: California.

KAPLAN, S., Manca, F., Nielsen, T. A. S. and Prato, C. G., (2015). Intentions to use bikesharing for holiday cycling: an application of the theory of planned behavior. Tourism Management. 47: 34-46.

KEELING, A. (1999). The National Cycle Network: Boosting UK Cycle Tourism, In. Sustrans 1999 Cycle tourism information pack.

KOCH, K. (2013). Bicycle tourism in Hungary. Apstract - Applied Studies in Agribusiness and Commerce, 7: 67-72.

KOÇAK, F. (2016). Türkiye'de bisiklet kullanımı: Bisiklet kullanma nedenleri ve elde edilen faydalar. Journal of Human Sciences, 13 (3): 5760-5771.

LAMONT, M. (2009). Reinventing the wheel: a definitional discussion of bicycle tourism. Journal of Sport And Tourism, 14 (1): 5-23.

LANCESTER, E. (n.d.) European Cyclist's Federation What we do, Cycling Tourism. Retrieved December 20, 2016, from https://ecf.com

LEE, C. F. and Huang, H. I. (2014). The attractiveness of taiwan as a bicycle tourism destination: a supply-side approach, Asia Pacific Journal of Tourism Research, 19(3): 273-299.

LARSON, J. (1995). The bicycle market. American Demographics 17(3): 42-48.

LU, D. (2010). Cycling tourism in China. Retrieved from http://www.dovenbike.com/ Doven_CyclingInChina.pdf

LUMSDON, L. (2000). Transport and tourism: cycle tourism - a model for sustainable development?. Journal of Sustainable Tourism. 8(5): 361-377.

MORPETH, N. (2001). The renaissance of cycle tourism. special interest tourism, Brisbane : J. Wiley \& Sons Australia.

NICKERSON, N. P., Jorgenson, J. D.; Berry, M., Kwenye, J., Kozel, D. and Schutz, J. (2014). Bicycle tourism: providing economic development opportunities for Montana. Institute for Tourism and Recreation Research Publications. Retrieved from http://scholarworks.umt.edu/itrr_pubs/322.

OKONSKİ, M. M. (2016). Bike touring infrastructure: an architectural proposal for sustainable bicycle tourism. University of Washington. Retrieved from http://hdl.handle.net/1773/36399

PATTON, M., Q. (2002), Qualitative Research and Evaluation Methods, Thousand Oaks CA:Sge.

PAYNE, K. C. and Dror, M. (2015). Multi-day bicycle tour route generation. Journal of Quantitative Analysis in Sports, 11(2): 85-96.

PIKET, P., Eijgelaar, E. and Peeters, P. (2013) European cycle tourism: A tool for sustainable regional rural development. Applied Studies in Agribusiness and Commerce, p. 115119. 
POMFRET, G. (2006). Mountaineering adventure tourists: a conceptual framework for research. Tourism Management. 27 (1): 113-123.

PORTER, L. W., and Lawler, E. E. (1968). Managerial Attitudes and Performance. Homewood, IL: Irwin-Dorsey.

RITCHIE, B. W. (1998) Bicycle tourism in the South Island of New Zealand: planning and management issues, Tourism Management 19(6): 567-582.

RITCHIE, B. W. and Hall, C. M. (1999). Bicycle tourism and regional development: A New Zealand case study. Anatolia: An international journal of tourism and hospitality research 10(2): 89-112.

SIMONSEN, P. S., Jorgensen, B. and Robbins, D. (1998) Cycling tourism, report 13/98, Bornholm: Reseach Centre of Bornholm.

SOUTH Australian Tourism Commission (2005). Cycle tourism strategy 2005-2009. Retrieved January 11, 2017, from http://www.tourism.sa.gov.au/tourism/plan/cycley_tourism_strategy.pdf

SUNG, H. H. (2000). An analysis of the adventure travel market: from conceptual development to market segmentation, PhD, Purdue University.

SUSTRANS, (2015). Sustrans' Annual Review 2014-15. Retrieved January 5, 2017, from http://www.sustrans.org.uk

SUSTRANS, (1999). Cycle tourism information pack. Retrieved January 7, 2017, from http://www.sustrans.org.uk

WEBER, K. (2001). Outdoor adventure tourism a review of research approaches. Annals of Tourism Research, 28 (2): 360-377.

WILSON, D. G. (2004). Bicycling science, The Mit Press: Cambridge. Retrieved from http://www.cycling-embassy.org.uk 